\title{
Differentially expressed long non-coding RNAs and the prognostic potential in colorectal cancer
}

Q. $\mathrm{LI}^{1, *}, \mathrm{Y} . \mathrm{DAI}^{2, *}, \mathrm{~F} . \mathrm{WANG}^{2}, \mathrm{~S} . \mathrm{HOU}^{3, *}$

${ }^{1}$ Department of Clinical Laboratory, The First Hospital of Zibo City, Zibo 255200, Shandong, China; ${ }^{2}$ Department of General Surgery, Zoucheng People's Hospital, Zoucheng 273500, Shandong, China; ${ }^{3}$ Department of Pediatric Surgery, Zoucheng People's Hospital, Zoucheng 273500, Shandong, China

*Correspondence: housu5981@126.com

${ }^{*}$ Contributed equally to this work.

Received April 7, 2016 / Accepted June 9, 2016

Colorectal cancer (CRC) is a disease with high incidence, especially in developed countries. Long non-coding RNAs (lncRNAs) are new research hotspots for their vital roles in regulating gene expression. This study aims to investigate the prognostic value of lncRNAs in CRC patients.

A total of 21 cancer-related lncRNAs were detected by PCR array to reveal their expression changes in CRC tissue. A 120 -week-long follow-up was performed in 30 CRC patients to analyze the relationship between lncRNA levels and CRC prognosis.

Most of the 21 lncRNAs were differentially expressed in CRC tissue compared to the adjacent normal tissue, among which seven lncRNAs were significantly changed: AFAP1-AS1, BCAR4, H19, HOXA-AS2, MALAT1 and PVT1 were up-regulated, and ADAMTS9-AS2 was down-regulated in CRC tissue samples. No obvious correlation was found between lncRNA levels and the age, gender, tumor size or TNM stage of these patients. Log-rank test indicated that higher levels of AFAP1-AS1, BCAR4, H19, HOXA-AS2, MALAT1 or PVT1 and lower level of ADAMTS9-AS2 might predict the poor prognosis of CRC patients.

This study suggests the potential value of the seven lncRNAs in the prognosis of CRC, providing reference information for future research on CRC prognostic and treatment strategy.

Key words: colorectal cancer (CRC), long non-coding RNAs, prognosis, differential expression

Colorectal cancer (CRC) is the cancer developed in the colon or rectum. It has a high incidence in developed countries and has become the third most common cancer and the third leading cause of cancer death in the United States [1]. Patients with CRC suffer from symptoms like hematochezia, changes in the bowel movements and weight loss. Risk factors include unhealthy lifestyle such as smoking and alcohol, older age and inherited genetic disorders $[2,3]$. Treatments of CRC involve the combination of surgery, radiation therapy, chemotherapy and targeted therapy. For example, colonoscopic polypectomy may help to prevent death from CRC [4], and screening with flexible sigmoidoscopy is capable of decreasing incidence of CRC [5]. Various screening strategies are adopted by European countries [6]. Although the death rate has declined in the past decade due to the improvement of screening and standard treatment, the frequency of relapses and the poor prognosis still greatly impact the outcome of treating CRC. Thus effective prevention and treatment of CRC is not an easy task.

Numerous studies intensively focused on the pathology of $\mathrm{CRC}$ and have revealed the central role of Wnt signaling in the etiology of CRC [7]. Tumor suppressor adenomatous polyposis coli (APC) protein also possesses a significant position that may cause CRC. Mutation in APC gene leads to uncontrolled accumulation of $\beta$-catenin, which activates the expression of proto-oncogenes [8]. In addition to $A P C$, mutations in TP53, SMAD4, SOX9, as well as the abnormal DNA copy number, promoter methylation and microsatellite instability have also been uncovered in CRC patients with the help of genomescale analyses [9].

PCR array is a high throughput method to detect gene expression conveniently and reliably, which has contributed 
to the revelation of key factors in CRC, such as interleukins [10] and DEAH box polypeptide 32 [11]. However, few studies refered to a wide-range expression profile of long non-coding RNAs (lncRNAs) in CRC. lncRNAs are non-coding RNAs longer than $200 \mathrm{nt}$, participating in diverse cellular activities as key regulators of gene expression. Some lncRNAs, such as ADAMTS9-AS2, are tumor suppressors [12], while some may facilitate tumor development and progression, among which MALAT1 and AFAP1-AS1 have been reported as therapeutic targets for cancers $[13,14]$. A recent study found that 761 lncRNAs were hypermethylated in CRC tissue samples [15], further emphasizing the role of IncRNAs in CRC development. Still, more expression profiles and the application value of lncRNAs in CRC need to be investigated.

This study aimed at revealing the role of $\operatorname{lncRNAs}$ in the prognosis of CRC. We selected 21 cancer-related lncRNAs that might be involved in cancer development according to existed researches (Supplementary Table), and detected their expression in CRC tissue samples compared to normal samples by means of PCR array. Seven of these lncRNAs were identified to be up- or down-regulated in CRC. A 120-week-long follow-up was performed on $30 \mathrm{CRC}$ patients to investigate the possible prognostic role of the seven lncRNAs in CRC. These results will provide proof for the application of lncRNAs in CRC prognosis.

\section{Materials and methods}

Clinical samples. A total of 15 female and 15 male patients (Table 1) diagnosed with CRC were selected from the patients that underwent radical surgical resection during 2010 to 2013. None of the patients had accepted chemotherapy or radiotherapy before the surgery. The cancer tissue and adjacent normal tissue samples were obtained during the surgery. All patients were informed with the experiment before sampling. The tissue samples were frozen in liquid nitrogen immediately after the sampling procedure, and stored at $-80^{\circ} \mathrm{C}$ until RNA extraction. The cancer tissue samples were pathologically examined and staged according to the $7^{\text {th }}$ version of the American Joint Committee on Cancer (AJCC) cancer staging system. After the surgery, a follow-up of 120 weeks was performed on

Table 1. Age, gender, tumor size and TNM stage information of the 30 colorectal patients used in this study.

\begin{tabular}{llc}
\hline Variables & & Number (\%) \\
\hline Age (years) & $<60$ & $18(60)$ \\
& $\geq 60$ & $12(40)$ \\
Gender & Female & $15(50)$ \\
& Male & $15(50)$ \\
Tumor size & Rectum & $16(53.3)$ \\
& Colon & $14(46.7)$ \\
TNM stage & II & $20(66.7)$ \\
& III & $10(33.3)$ \\
\hline
\end{tabular}

TNM, tumor node metastasis. each patient via reexamination or phone call. This study was approved by a local ethics committee. Three of the 30 patients were randomly selected and their tissue samples were used in PCR array.

RNA extraction and reverse transcription. Total RNAs from tissue samples were extracted with Trizol (Invitrogen, Carlsbad, CA) and purified with PureLink RNA Mini Kit (Thermo Scientific, Carlsbad, CA) according to the manufacturers' instructions. The quality and quantity of RNAs were examined by agarose gel electrophoresis and NanoDrop 2000 (Thermo Scientific). First-strand complementary DNAs (cDNAs) were synthesized with RevertAid First Strand cDNA Synthesis Kit (Thermo Scientific).

PCR array. Three of the 30 patients were randomly selected and their tissue samples were used in PCR array after RNA extraction and reverse transcription. The cDNA samples were used for PCR array by TaqMan Gene Expression Assays (Applied Biosystems, Carlsbad, CA) with specific primers for 21 lncRNAs according to the manufacturer's instruction. The assay was performed on QuantStudio ${ }^{\mathrm{TM}} 6$ Flex Realtime PCR System (Applied Biosystems). GAPDH was used as an internal control.

qPCR. The expressions of seven up- or down-regulated lncRNAs in each tissue sample of 30 patients were examined on QuantStudio ${ }^{\mathrm{TM}} 6$ Flex Realtime PCR System using the specific primers for these IncRNAs (Table 2). Detection was repeated in triplicate. Data were analyzed by $2^{-\Delta \Delta \mathrm{Ct}}$ method with GAPDH as an internal control.

Statistical analysis. Data were represented as the mean \pm standard deviation and analyzed with SPSS 20 (IBM, New York, NY). Comparison between groups was performed by $t$ test, and categorical data were analyzed by Fisher's exact test. In the survival curve assay, loss of follow-up and the

Table 2. Specific primers of seven lncRNAs and GAPDH used in qPCR.

\begin{tabular}{|c|c|}
\hline Primer & Sequence ( 5 ' to $3^{\prime}$ ) \\
\hline \multirow{2}{*}{ AFAP1-AS1 } & (Fw) GGAGTGACGGCATCCAACTC \\
\hline & (Rv) GTCATCCCTGTCCCTGGTTC \\
\hline \multirow{2}{*}{ BCAR4 } & (Fw) CTTGCAGAAAACCACGAGGC \\
\hline & (Rv) CAGCGAGGTGCTAGCGATTA \\
\hline \multirow{2}{*}{ H19 } & (Fw) GGAGACTAGGCCAGGTCTC \\
\hline & (Rv) GCCCATGGTGTTCAAGAAGGC \\
\hline \multirow{2}{*}{ HOXA-AS2 } & (Fw) GGCGTTTCCTTTTCCCACAG \\
\hline & (Rv) GTCAACGGATTTGGTCTGTATT \\
\hline \multirow{2}{*}{ MALAT1 } & (Fw) CAGTGGGGAACTCTGACTCG \\
\hline & (Rv) GTGCCTGGTGCTCTCTTACC \\
\hline \multirow[b]{2}{*}{ PVT1 } & (Fw) TGCTCTAGAATCTGATGCACGTTCCACC \\
\hline & $\begin{array}{l}\text { (Rv) CCGGAATTCCTTAATTCTCCAATCT- } \\
\text { CAAAATAC }\end{array}$ \\
\hline \multirow{2}{*}{ ADAMTS9-AS2 } & (Fw) GACCCTCTTCCAGAAGGCAC \\
\hline & (Rv) GGACAAGCGAAGGACATCC \\
\hline \multirow{2}{*}{ GAPDH } & (Fw) ATCCATCCATAATGGCTTCC \\
\hline & (Rv) AGTCTTCTGGGTGGCAGTGAT \\
\hline
\end{tabular}


survival when the follow-up ended were considered as censored data. Survival curves were analyzed by log-rank test or Cox's proportional hazards regression model. PCR array data were analyzed by DataAssist ${ }^{\mathrm{TM}}$ Software (Applied Biosystems) using the $2^{-\Delta \Delta \mathrm{Ct}}$ method. Fold change was calculated as the normalized lncRNA expression in the cancer tissue samples divided the normalized expression in the normal tissue samples. In data analysis, $P<0.05$ was considered as statistically significant.

\section{Results}

Fold changes of lncRNAs in CRC tissue. Based on the PCR array results, the expression levels of 21 lncRNAs in the cancer tissue samples of three patients were compared to their expression in the corresponding adjacent normal tissue after normalized by GAPDH. The heat map showed that HNF1A-AS1, ADAMTS9-AS2, BANCR and TUSC7 might possess of higher levels in normal tissue samples and 14 lncRNAs were relatively up-regulated in cancer tissue samples (Figure 1). It should be noticed that differences among the three patients could be observed, since the expression of some lncRNAs like ACTA2-AS1 and CBR3-AS1 were obviously down-regulated in the adjacent normal tissue sample of patient No. 1 while almost unchanged in patient No. 2 compared to cancer tissue samples.

Data analysis calculated the fold changes of each lncRNA in cancer tissue compared to adjacent normal tissue samples

Table 3. Fold changes of 21 lncRNAs detected by qPCR array.

\begin{tabular}{|c|c|c|c|}
\hline Symbol & Fold change & $95 \% \mathrm{Cl}$ & $P$ value \\
\hline ACTA2-AS1 & 1.271 & $(0.96,1.58)$ & 0.117998 \\
\hline BLACAT1 & 1.169 & $(0.92,1.42)$ & 0.219244 \\
\hline BANCR & 0.6717 & $(0.58,0.77)$ & $0.005683^{*}$ \\
\hline HNF1A-AS1 & 0.8078 & $(0.65,0.96)$ & 0.097723 \\
\hline TUSC7 & 0.7768 & $(0.69,0.86)$ & $0.013389^{*}$ \\
\hline ADAMTS9-AS2 & 0.4416 & $(0.33,0.56)$ & $0.012486^{*}$ \\
\hline AFAP1-AS1 & 2.4529 & $(2.14,2.77)$ & $0.00062^{\star}$ \\
\hline BCAR4 & 4.0113 & $(3.48,4.55)$ & $0.000015^{\star}$ \\
\hline CCAT1 & 1.3478 & $(1.23,1.47)$ & $0.002568^{*}$ \\
\hline CCAT2 & 1.1599 & $(0.99,1.33)$ & 0.115921 \\
\hline CBR3-AS1 & 1.1336 & $(0.86,1.41)$ & 0.380373 \\
\hline HAND2-AS1 & 1.5859 & $(1.19,1.99)$ & $0.027724^{*}$ \\
\hline JADRR & 1.1604 & $(1.03,1.30)$ & 0.066514 \\
\hline CRNDE & 1.8058 & $(1.58,2.03)$ & $0.000446^{\star}$ \\
\hline H19 & 2.1165 & $(1.72,2.52)$ & $0.0004^{*}$ \\
\hline HEIH & 1.3849 & $(1.22,1.55)$ & $0.004886^{*}$ \\
\hline SNHG16 & 1.0711 & $(0.90,1.24)$ & 0.44561 \\
\hline HOXA-AS2 & 2.2759 & $(1.97,2.58)$ & $0.000175^{*}$ \\
\hline HOTAIR & 1.7209 & $(1.45,1.99)$ & $0.00232^{\star}$ \\
\hline MALAT1 & 7.6984 & $(3.74,11.66)$ & $0.003436^{*}$ \\
\hline PVT1 & 4.4358 & $(1.21,7.66)$ & $0.01295^{\star}$ \\
\hline GAPDH & 0.9997 & $(0.93,1.07)$ & 0.998402 \\
\hline
\end{tabular}

${ }^{\star} P<0.05$. lncRNAs with a change fold larger/lower than 2 are in bold. of the three patients (Table 3). The expression level change of more than two folds was considered as up- or down-regulated $\operatorname{lncRNAs}$, thus seven of the lncRNAs were filtered out, all of which possessed significant expression changes between cancer and adjacent normal tissue samples $(P<0.05)$. Among them, AFAP1-AS1, BCAR4, H19, HOXA-AS2, MALAT1 and PVT1 were significantly up-regulated, and ADADMTS9-AS2 was significantly down-regulated in cancer tissue samples. The histograms in Figure 2 showed the expression level comparison of the seven lncRNAs more directly. These results implied that the seven IncRNAs found by PCR array might be involved in the progression or development of CRC.

Prognostic potential of seven lncRNAs in CRC. Before the survival curve assay, we performed $\chi^{2}$ test on the relationship between IncRNA levels and the age, gender, tumor size or

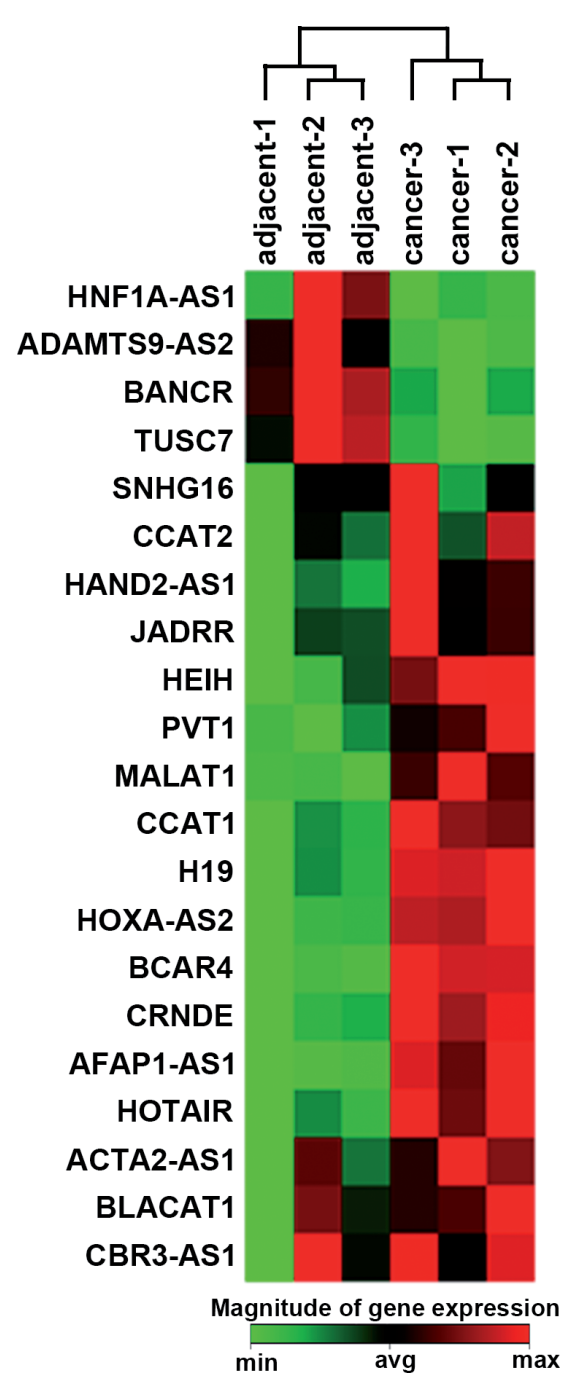

Figure 1 Heat map of 21 lncRNAs expression levels in cancer and adjacent normal tissue samples of CRC patients $(n=3)$. Adjacent- 1 and cancer-1 samples are from the same patient, and so on. Expression level from low to high is represented as green to red. 
A

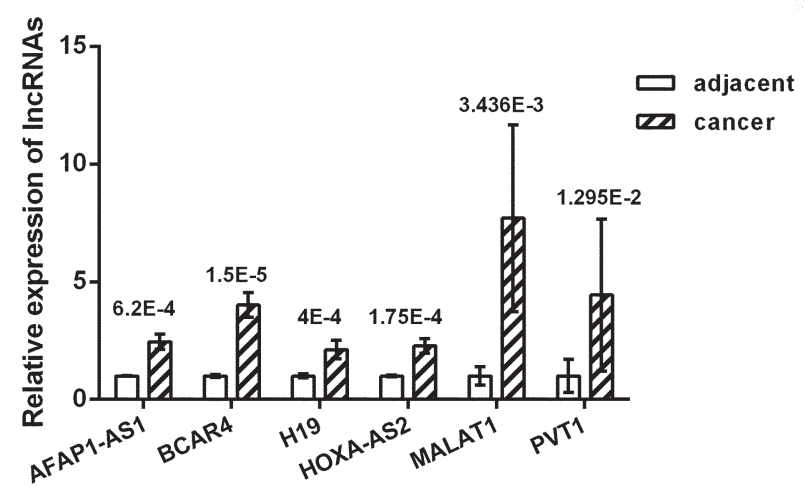

B

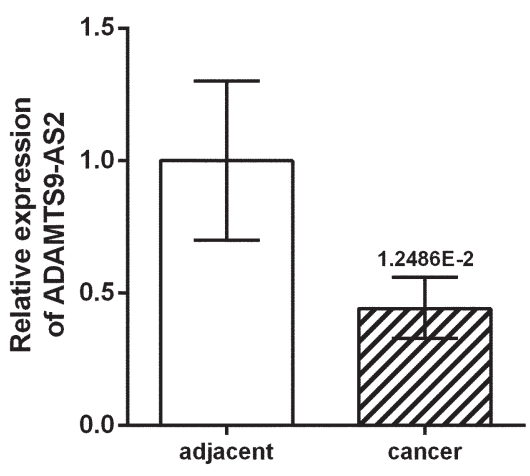

Figure 2. Histogram showing the significantly up-regulated and down-regulated IncRNAs in CRC tissue samples compared to adjacent normal tissue samples based on PCR array results $(\mathrm{n}=3)$. (A) IncRNAs that are up-regulated in CRC tissue samples. (B) lncRNA ADAMTS9-AS2 is down-regulated in CRC tissue samples. $P$ values are indicated above each comparison.

TNM stage of the 30 patients, and no obvious association was found $(P>0.05$, Table 4$)$. When the 30 patients were divided into two groups - 15 patients with high AFAP1-AS1 levels and 15 patients with lower AFAP1-AS1 levels - the survival curve assay indicated that the patients with higher AFAP1-AS1 levels had a relatively shorter survival time than patients in the other group ( $P=0.0103$, Figure 3 and Table 5). Similar results were also detected from BCAR4, H19, HOXA-AS2, MALAT1 and PVT1. However, patients with higher ADAMTS9-AS2 levels had a relatively longer survival time $(P=0.0046)$. Thus $\operatorname{lncRNA}$
AFAP1-AS1, BCAR4, H19, HOXA-AS2, MALAT1 and PVT1 might be correlated with a worse prognosis and ADAMTS9AS2 might indicate a better prognosis for CRC patients.

\section{Discussion}

As hotspots of gene regulation research, lncRNAs and their pivotal position in cancer modulation have been gradually revealed. This study examined the expression profile of 21 cancer-related lncRNAs in cancer tissue samples of

Table 4. Association between lncRNA levels and variables of patients $(n=30)$.

\begin{tabular}{|c|c|c|c|c|c|c|c|c|c|}
\hline & & \multicolumn{2}{|c|}{ Age (years) } & \multicolumn{2}{|c|}{ Gender } & \multicolumn{2}{|c|}{ Tumor site } & \multicolumn{2}{|c|}{ TNM stage } \\
\hline & & $<60$ & $\geq 60$ & Female & Male & Rectum & Colon & II & III \\
\hline \multirow{3}{*}{ AFAP-AS1 } & High $(\mathrm{n}=15)$ & 8 & 7 & 6 & 9 & 7 & 8 & 10 & 5 \\
\hline & Low $(n=15)$ & 10 & 5 & 9 & 6 & 9 & 6 & 10 & 5 \\
\hline & $P$ value & 0.7104 & & 0.4661 & & 0.7152 & & 1.0000 & \\
\hline \multirow{3}{*}{ BCAR4 } & $\operatorname{High}(\mathrm{n}=15)$ & 9 & 6 & 7 & 8 & 9 & 6 & 9 & 6 \\
\hline & Low $(n=15)$ & 10 & 5 & 8 & 7 & 6 & 9 & 11 & 4 \\
\hline & $P$ value & 1.0000 & & 1.0000 & & 0.4661 & & 0.6999 & \\
\hline \multirow{3}{*}{ H19 } & High $(\mathrm{n}=15)$ & 8 & 7 & 8 & 7 & 9 & 6 & 12 & 3 \\
\hline & Low $(n=15)$ & 10 & 5 & 7 & 8 & 7 & 8 & 8 & 7 \\
\hline & $P$ value & 0.7104 & & 1.0000 & & 0.7152 & & 0.2451 & \\
\hline \multirow{3}{*}{ HOXA-AS2 } & $\operatorname{High}(\mathrm{n}=15)$ & 9 & 6 & 6 & 9 & 9 & 6 & 9 & 6 \\
\hline & Low $(n=15)$ & 9 & 6 & 9 & 6 & 8 & 7 & 10 & 5 \\
\hline & $P$ value & 1.0000 & & 0.4661 & & 1.0000 & & 1.0000 & \\
\hline \multirow{3}{*}{ MALAT1 } & High $(\mathrm{n}=15)$ & 10 & 5 & 7 & 8 & 10 & 5 & 11 & 4 \\
\hline & Low $(n=15)$ & 8 & 7 & 8 & 7 & 7 & 8 & 9 & 6 \\
\hline & $P$ value & 0.7104 & & 1.0000 & & 0.4621 & & 0.6999 & \\
\hline \multirow{3}{*}{ PVT1 } & High $(\mathrm{n}=15)$ & 9 & 6 & 6 & 9 & 9 & 6 & 11 & 4 \\
\hline & Low $(n=15)$ & 9 & 6 & 9 & 6 & 7 & 8 & 9 & 6 \\
\hline & $P$ value & 1.0000 & & 0.4661 & & 0.7152 & & 0.6999 & \\
\hline \multirow{3}{*}{ ADAMTS-AS2 } & High $(\mathrm{n}=15)$ & 10 & 5 & 8 & 7 & 7 & 8 & 10 & 5 \\
\hline & Low $(\mathrm{n}=15)$ & 8 & 7 & 7 & 8 & 9 & 6 & 10 & 5 \\
\hline & $P$ value & 0.7104 & & 1.0000 & & 0.7152 & & 1.0000 & \\
\hline
\end{tabular}



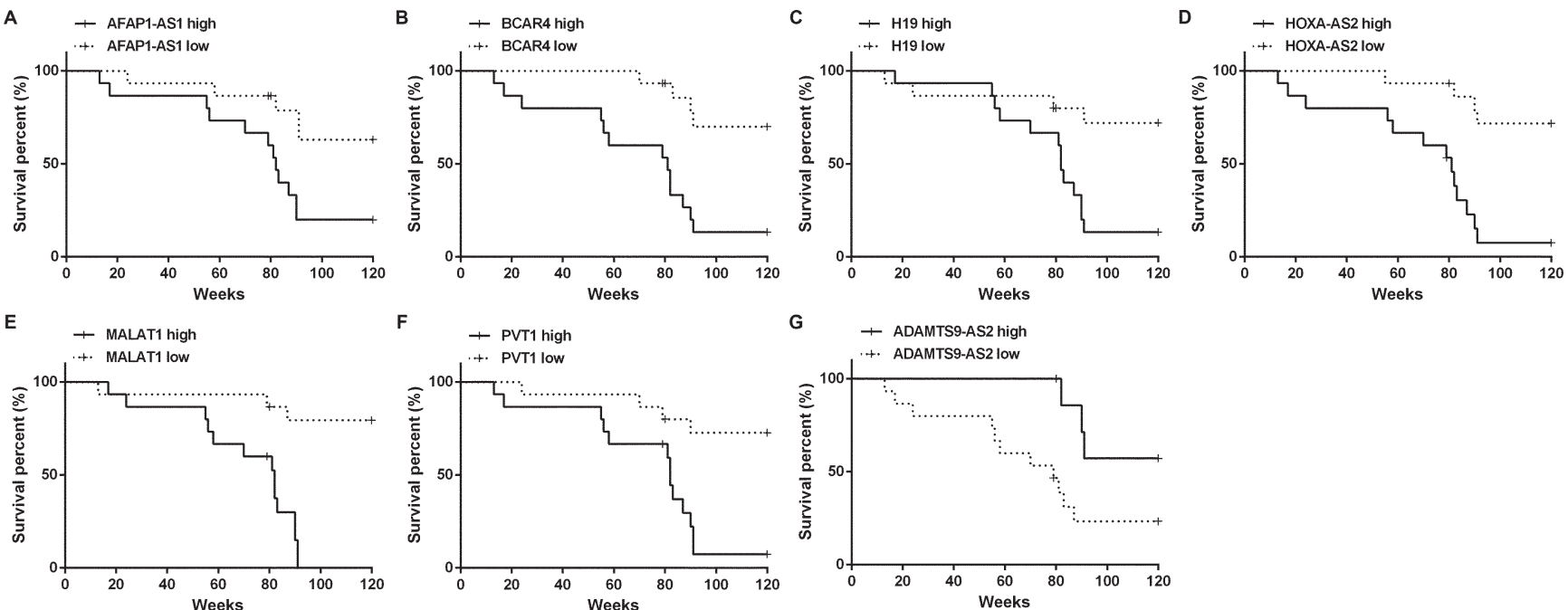

Figure 3. Survival curves of seven IncRNAs and the survival percent of colorectal patients $(n=30)++$ indicates censored data due to loss of follow-up and the survival when the 120-week-long follow-up ended. For each survival curve assay, the 30 patients are divided into two groups according to the higher or lower AFAP1-AS1 (A), BCAR4 (B), H19 (C), HOXA-AS2 (D), MALAT1 (E), PVT1 (F) or ADAMTS9-AS2 (G) levels.

CRC patients and screened seven lncRNAs that had significantly aberrant expression between cancer and normal tissue samples. The follow-up and survival curve assay of these seven lncRNAs implied their possible relationship with CRC prognosis.

Among the 21 lncRNAs detected by PCR array, some were up-regulated and some were down-regulated to some extent compared to their expressions in normal tissue samples. In consistent with existed studies of gastric cancer and hepatocellular carcinoma, that HNF1A-AS1 and TUSC7 were down-regulated and acted as tumor suppressors [16, 17], this study also detected lower expression of the two lncRNAs in CRC samples. In malignant melanoma, BANCR was upregulated and promoted tumor growth [18], whereas it was inhibited in CRC samples. We conjectured this discrepancy may generate from individual difference or specific regulatory mechanisms of lncRNAs in different cancer cells.

By setting the expression change threshold to 2 folds, we screened seven lncRNAs that had significantly up- or downregulated expression in CRC tissue samples. Among the seven IncRNAs, AFAP1-AS1, BCAR4, H19, HOXA-AS2, MALAT1 and PVT1 were up-regulated, while ADAMTS9-AS2 was down-regulated. AFAP1-AS1 has been found hypomethylated in Barrett's esophagus and esophageal adenocarcinoma, which led to its overexpression [19]. BCAR4 has been discovered overexpressing in breast cancer [20]. Overexpression of H19 was found in gastric cancer, breast cancer and bladder cancer, enhancing carcinogenesis and cancer metastasis [21-23]. Similarly, HOXA-AS2, MALAT1 and PVT1 were all reported to be up-regulated in cancer cells and promoted cancer progression [24-26]. As for ADAMTS9-AS2, it was revealed to be a cancer suppressor factor that lower expressed in glioma cells, with its overexpression inhibiting glioma cell migration [12]. Together with the findings of this study, it could be deduced that the seven IncRNAs have relatively conserved expression pattern in various cancers including CRC. Their aberrant levels in CRC tissue compared to normal tissue may imply the involvement of these lncRNAs in the development and progression of CRC, which needs to be investigated in further research.

An important finding of this study is the relationship between the seven IncRNAs and the prognosis of CRC. CRC patients with lower AFAP1-AS1, BCAR4, H19, HOXA-AS2, MALAT1 or PVT1 levels, or a higher ADAMTS9-AS2 level tended to show better prognosis. Some of these $\operatorname{lncRNAs}$ have been investigated in cancers to of possess potential prognostic values. For example, the low ADAMTS9-AS2 expression was a predictor for poor survival in glioma [12]. Poor prognosis in renal cell carcinoma, nasopharyngeal carcinoma, nonsmall-cell lung cancer and cervical cancer has also been found related to high expression of H19 [27], AFAP1-AS1 [28, 29] and MALAT1 [30]. Similar to the former studies, higher AFAP1-AS1, BCAR4, H19, HOXA-AS2, MALAT1 or PVT1 levels and lower ADAMTS9-AS2 level may also predict a poor prognosis of CRC.

Table 5. Log-rank test results of survival curves.

\begin{tabular}{lcc}
\hline lncRNA & $P$ value & $\chi^{2}$ value \\
\hline AFAP1-AS1 & 0.0103 & 6.574 \\
BCAR4 & 0.0005 & 12.29 \\
H19 & 0.0038 & 8.354 \\
HOXA-AS2 & 0.0001 & 14.51 \\
MALAT1 & $<0.0001$ & 16.53 \\
PVT1 & 0.0011 & 10.60 \\
ADAMTS9-AS2 & 0.0046 & 8.039 \\
\hline
\end{tabular}


Existed prognostic markers for CRC included miRNAs, some genome signatures like microsatellite instability and gene copy number, as well as other factors like CD133 [31-34]. The seven lncRNAs that were up- or down-regulated in CRC tissue sample may have great potential in CRC prognosis. Our future research will concentrate on exploring more accurate prognostic methods for CRC, possibly via combining multiple lncRNAs. Moreover, the detailed functions and regulatory mechanism of these lncRNAs in CRC are worth discussing, which may provide more useful informations for controlling CRC and other cancers.

In summary, this study revealed seven lncRNAs with aberrant expression in CRC tissue samples: AFAP1-AS1, BCAR4, H19, HOXA-AS2, MALAT1 and PVT1 were up-regulated, and ADAMTS9-AS2 was down-regulated. The expression of the seven IncRNAs was associated with the prognosis of CRC patients. These results provided potential prognostic alternatives for the prediction of CRC outcome and the exploration of prognostic strategies.

Supplementary information is available in the online version of the paper.

\section{References}

[1] SIEGEL R, DESANTIS C and JEMAL A. Colorectal cancer statistics, 2014. CA Cancer J Clin 2014; 64: 104-117. http:// dx.doi.org/10.3322/caac. 21220

[2] MOSHER CE, SLOANE R, MOREY MC, SNYDER DC, COHEN HJ et al. Associations between lifestyle factors and quality of life among older long-term breast, prostate, and colorectal cancer survivors. Cancer 2009; 115: 4001-4009. http://dx.doi.org/10.1002/cncr.24436

[3] CHURCH J, KIRINGODA R and L. L. Inherited colorectal cancer registries in the United States. Dis Colon Rectum 2004; 47: 674-678. http://dx.doi.org/10.1007/s10350-003-0115-5

[4] G. ZA, WINAWER SJ, O'BRIEN MJ, LANSDORP-VOGELAAR I, VAN BALLEGOOIJEN M et al. Colonoscopic Polypectomy and Long-Term Prevention of Colorectal-Cancer Deaths. N Engl J Med 2012; 366: 687-696. http://dx.doi. org/10.1056/NEJMoa1100370

[5] SCHOEN RE, PINSKY PF, WEISSFELD JL, YOKOCHI LA, $\mathrm{CHURCH} \mathrm{T}$ et al. Colorectal-cancer incidence and mortality with screening flexible sigmoidoscopy. N Engl J Med 2012; 366: 2345-2357. http://dx.doi.org/10.1056/NEJMoa1114635

[6] ALTOBELLI E, LATTANZI A, PADUANO R, VARASSI $\mathrm{G}$ and DI ORIO F. Colorectal cancer prevention in Europe: burden of disease and status of screening programs. Prev Med 2014; 62: 132-141. http://dx.doi.org/10.1016/j. ypmed.2014.02.010

[7] BIENZ M and CLEVERS H. Linking colorectal cancer to Wnt signaling. Cell 2000; 103: 311-320. http://dx.doi.org/10.1016/ $\underline{\text { S0092-8674(00)00122-7 }}$

[8] SPARKS AB, MORIN PJ, VOGELSTEIN B and KINZLER KW. Mutational analysis of the APC/beta-catenin/Tcf pathway in colorectal cancer. Cancer Res 1998; 58: 1130-1134.
[9] CANCER GENOME ATLAS N. Comprehensive molecular characterization of human colon and rectal cancer. Nature 2012; 487: 330-337. http://dx.doi.org/10.1038/nature11252

[10] EDIN S, WIKBERG ML, RUTEGARD J, OLDENBORG PA and PALMQVIST R. Phenotypic skewing of macrophages in vitro by secreted factors from colorectal cancer cells. PLoS One 2013; 8: e74982. http://dx.doi.org/10.1371/journal. pone. 0074982

[11] LIN H, LIU W, FANG Z, LIANG X, LI J et al. Overexpression of DHX32 contributes to the growth and metastasis of colorectal cancer. Sci Rep 2015; 5: 9247. http://dx.doi.org/10.1038/ $\underline{\text { srep09247 }}$

[12] YAO J, ZHOU B, ZHANG J, GENG P, LIU K et al. A new tumor suppressor LncRNA ADAMTS9-AS2 is regulated by DNMT1 and inhibits migration of glioma cells. Tumour Biol 2014; 35: 7935-7944. http://dx.doi.org/10.1007/s13277-0141949-2

[13] HU L, WU Y, TAN D, MENG H, WANG K et al. Upregulation of long noncoding RNA MALAT1 contributes to proliferation and metastasis in esophageal squamous cell carcinoma. J Exp Clin Cancer Res 2015; 34: 7. http://dx.doi. org/10.1186/s13046-015-0123-Z

[14] YE Y, CHEN J, ZHOU Y, FU Z, ZHOU Q et al. High expression of AFAP1-AS1 is associated with poor survival and short-term recurrence in pancreatic ductal adenocarcinoma. J Transl Med 2015; 13: 137. http://dx.doi.org/10.1186/s12967015-0490-4

[15] LIAO Q, HE W, LIU J, CEN Y, LUO L et al. Identification and functional annotation of IncRNA genes with hypermethylation in colorectal cancer. Gene 2015; 572: 259-265. http:// dx.doi.org/10.1016/j.gene.2015.07.028

[16] DANG Y, LAN F, OUYANG X, WANG K, LIN Y et al. Expression and clinical significance of long non-coding RNA HNF1A-AS1 in human gastric cancer. World Journal of Surgical Oncology 2015; 13: http://dx.doi.org/10.1186/ s12957-015-0706-3

[17] WANG Y, LIU Z, YAO B, DOU C, XU M et al. Long noncoding RNA TUSC7 acts a molecular sponge for miR-10a and suppresses EMT in hepatocellular carcinoma. Tumor Biology 2016; http://dx.doi.org/10.1007/s13277-016-4892-6

[18] DADRAS SS, LI R, ZHANG L, JIA L, DUAN Y et al. Long Non-Coding RNA BANCR Promotes Proliferation in Malignant Melanoma by Regulating MAPK Pathway Activation. PLoS ONE 2014; 9: e100893. http://dx.doi.org/10.1371/ journal.pone.0100893

[19] WU W, BHAGAT TD, YANG X, SONG JH, CHENG Y et al. Hypomethylation of Noncoding DNA Regions and Overexpression of the Long Noncoding RNA, AFAP1-AS1, in Barrett's Esophagus and Esophageal Adenocarcinoma. Gastroenterology 2013; 144: 956-966.e954. http://dx.doi. org/10.1053/j.gastro.2013.01.019

[20] XING Z, LIN A, LI C, LIANG K, WANG S et al. lncRNA Directs Cooperative Epigenetic Regulation Downstream of Chemokine Signals. Cell 2014; 159: 1110-1125. http://dx.doi. org/10.1016/j.cell.2014.10.013

[21] LI H, YU B, LI J, SU L, YAN M et al. Overexpression of lncRNA $\mathrm{H} 19$ enhances carcinogenesis and metastasis of gastric cancer. 
Oncotarget 2014; 5: 2318-2329. http://dx.doi.org/10.18632/ oncotarget.1913

[22] SUN H, WANG G, PENG Y, ZENG Y, ZHU QN et al. H19 lncRNA mediates $17 \beta$-estradiol-induced cell proliferation in MCF-7 breast cancer cells. Oncol Rep 2015; 33: 3045-3052. http://dx.doi.org/10.3892/or.2015.3899

[23] LUO M, LI Z, WANG W, ZENG Y, LIU Z et al. Long noncoding RNA H19 increases bladder cancer metastasis by associating with EZH2 and inhibiting E-cadherin expression. Cancer Lett 2013; 333: 213-221. http://dx.doi.org/10.1016/j. canlet.2013.01.033

[24] XIE M, SUN M, ZHU YN, XIA R, LIU YW et al. Long noncoding RNA HOXA-AS2 promotes gastric cancer proliferation by epigenetically silencing P21/PLK3/DDIT3 expression. Oncotarget 2015; 6: 33587-33601.

[25] YING L, CHEN Q, WANG Y, ZHOU Z, HUANG Y et al. Upregulated MALAT-1 contributes to bladder cancer cell migration by inducing epithelial-to-mesenchymal transition. Mol Biosyst 2012; 8: 2289-2294. http://dx.doi.org/10.1039/ c2mb25070e

[26] CUI M, YOU L, REN X, ZHAO W, LIAO Q et al. Long non-coding RNA PVT1 and cancer. Biochem Biophys Res Commun 2016; 471: 10-14. http://dx.doi.org/10.1016/j. bbrc.2015.12.101

[27] WANG L, CAI Y, ZHAO X, JIA X, ZHANG J et al. Downregulated long non-coding RNA H19 inhibits carcinogenesis of renal cell carcinoma. Neoplasma 2015; 62: 412-418. http:// dx.doi.org/10.4149/neo $2015 \quad 049$
[28] BO H, GONG Z, ZHANG W, LI X, ZENG Y et al. Upregulated long non-coding RNA AFAP1-AS1 expression is associated with progression and poor prognosis of nasopharyngeal carcinoma. Oncotarget 2015; 6: 20404-20418. http://dx.doi. org/10.18632/oncotarget.4057

[29] DENG J, LIANG Y, LIU C, HE S and WANG S. The up-regulation of long non-coding RNA AFAP1-AS1 is associated with the poor prognosis of NSCLC patients. Biomed Pharmacother 2015; 75: 8-11. http://dx.doi.org/10.1016/j.biopha.2015.07.003

[30] YANG L, BAI HS, DENG Y and FAN L. High MALAT1 expression predicts a poor prognosis of cervical cancer and promotes cancer cell growth and invasion. Eur Rev Med Pharmacol Sci 2015; 19: 3187-3193.

[31] BENATTI P, GAF R, BARANA D, MARINO M, SCARSELLI A et al. Microsatellite instability and colorectal cancer prognosis. Clin Cancer Res 2005; 11: 8332-8340. http://dx.doi. org/10.1158/1078-0432.CCR-05-1030

[32] MA Y, ZHANG P, WANG F, ZHANG H, YANG J et al. miR-150 as a potential biomarker associated with prognosis and therapeutic outcome in colorectal cancer. Gut 2012; 61: 1447-1453. http://dx.doi.org/10.1136/gutjnl-2011-301122

[33] BELOV L, ZHOU J and CHRISTOPHERSON RI. Cell surface markers in colorectal cancer prognosis. Int J Mol Sci 2010; 12: 78-113. http://dx.doi.org/10.3390/ijms12010078

[34] HORST D, KRIEGL L, ENGEL J, KIRCHNER T and JUNG A. CD133 expression is an independent prognostic marker for low survival in colorectal cancer. Br J Cancer 2008; 99: 1285-1289. http://dx.doi.org/10.1038/sj.bjc.6604664 
Supplementary Table: The 21 lncRNAs in this study and their related diseases in literature.

\begin{tabular}{ll}
\hline IncRNA & Disease in literature \\
\hline HNF1A-AS1 & lung adenocarcinoma [1], esophageal adenocarcinoma [2], \\
& gastric cancer [3] \\
ADAMTS9-AS2 & glioma [4], head and neck cancer [5] \\
BANCR & CRC [6], hepatocellular carcinoma [7], melanoma [8] \\
TUSC7 & non-small cell lung cancer [9], gastric cancer [10] \\
SNHG16 & thyroid cancer [11] \\
CCAT2 & cervical squamous cell cancer [12], breast cancer [13] \\
HAND2-AS1 & endometrial hyperplasia [14] \\
JADRR & breast cancer [15] \\
HEIH & hepatocellular carcinoma [16] \\
PVT1 & cervical carcinoma [17], pancreatic cancer [18] \\
MALAT1 & CRC [19], pancreatic cancer [20] \\
CCAT1 & CRC [21], hepatocellular carcinoma [21] \\
H19 & brostate cancer [37], esophageal squamous carcinoma [38] \\
HOXA-AS2 & gastric cancer [25], leukemia [26] \\
BCAR4 & breast cancer [27] \\
CRNDE & CRC [28], glioma [29] \\
AFAP1-AS1 & nallbladder cancer [32], urothelial cancer [33] \\
HOTAIR & lung adenocarcinoma [34] \\
\hline
\end{tabular}

References:

[1] WU Y, LIU H, SHI X, YAO Y, YANG W et al. The long non-coding RNA HNF1A-AS1 regulates proliferation and metastasis in lung adenocarcinoma. Oncotarget 2015; 6: 9160-9172.

[2] YANG X, SONG JH, CHENG Y, WU W, BHAGAT T et al. Long non-coding RNA HNF1A-AS1 regulates proliferation and migration in oesophageal adenocarcinoma cells. 
Gut 2014; 63: 881-890.

[3] DANG Y, LAN F, OUYANG X, WANG K, LIN Y et al. Expression and clinical significance of long non-coding RNA HNF1A-AS1 in human gastric cancer. World Journal of Surgical Oncology 2015; 13:

[4] YAO J, ZHOU B, ZHANG J, GENG P, LIU K et al. A new tumor suppressor LncRNA ADAMTS9-AS2 is regulated by DNMT1 and inhibits migration of glioma cells. Tumour Biol 2014; 35: 7935-7944.

[5] DEMIRCAN K, GUNDUZ E, GUNDUZ M, BEDER LB, HIROHATA S et al. Increased mRNA expression of ADAMTS metalloproteinases in metastatic foci of head and neck cancer. Head Neck 2009; 31: 793-801.

[6] LI AX, XIN WQ and MA CG. Fentanyl inhibits the invasion and migration of colorectal cancer cells via inhibiting the negative regulation of Ets-1 on BANCR. Biochem Biophys Res Commun 2015; 465: 594-600.

[7] YU X, ZHANG G, ZHAIO P, CUI M, WANG C et al. Downregulation of a long noncoding RNA BANCR contributes to proliferation and metastasis of hepatocellular carcinoma cancer cells in vitro and in vivo. Int J Clin Exp Pathol 2016; 9: 3304-3312.

[8] FLOCKHART RJ, WEBSTER DE, QU K, MASCARENHAS N, KOVALSKI J et al. BRAFV600E remodels the melanocyte transcriptome and induces BANCR to regulate melanoma cell migration. Genome Res 2012; 22: 1006-1014.

[9] WANG Z, JIN Y, REN H, MA X, WANG B et al. Downregulation of the long non-coding RNA TUSC7 promotes NSCLC cell proliferation and correlates with poor prognosis. Am J Transl Res 2016; 8: 680-687.

[10] QI P, XU MD, SHEN XH, NI SJ, HUANG D et al. Reciprocal repression between TUSC7 and miR-23b in gastric cancer. Int J Cancer 2015; 137: 1269-1278.

[11] TIAN S, RULLI S, FAHEY TJ and LADER E. IncRNA profiling and its potential usage as thyroid cancer biomarker. Cancer Research 2015; 75: 531.

[12] CHEN X, LIU L and ZHU W. Up-regulation of long non-coding RNA CCAT2 correlates with tumor metastasis and poor prognosis in cervical squamous cell cancer patients. Int $\mathrm{J}$ Clin Exp Pathol 2015; 8: 13261-13266.

[13] CAI Y, HE J and ZHANG D. Long noncoding RNA CCAT2 promotes breast tumor growth by regulating the Wnt signaling pathway. Onco Targets Ther 2015; 8: 2657-2664.

[14] FRANASIAK J, HUBBS J, OLORVIDA M, YOUNG S, GEHRIG P et al. HAND2 expression is increased in endometrial hyperplasia/cancer. Gynecol Oncol 213; 130: e89.

[15] WAN G, HU X, LIU Y, HAN C, SOOD AK et al. A novel non-coding RNA IncRNA-JADE connects DNA damage signalling to histone $\mathrm{H} 4$ acetylation. The EMBO Journal 2013; 32: 2833-2847.

[16] YANG F, ZHANG L, HUO XS, YUAN JH, XU D et al. Long noncoding RNA high expression in hepatocellular carcinoma facilitates tumor growth through enhancer of zeste homolog 2 in humans. Hepatology 2011; 54: 1679-1689.

[17] IDEN M, FYE S, RAMCHANDRAN R and RADER JS. Abstract 149: Overexpression of the long non-coding RNA PVT1 and its role in cervical carcinogenesis. Cancer Res 2015; 75: 149 .

[18] YOU L, CHANG D, DU HZ and ZHAIO YP. Genome-wide screen identifies PVT1 as a regulator of Gemcitabine sensitivity in human pancreatic cancer cells. Biochem Biophys 
Res Commun 2011; 407: 1-6.

[19] JI Q, ZHANG L, LIU X, ZHOU L, WANG W et al. Long non-coding RNA MALAT1 promotes tumour growth and metastasis in colorectal cancer through binding to SFPQ and releasing oncogene PTBP2 from SFPQ/PTBP2 complex. Br J Cancer 2014; 111: 736-748.

[20] PANG EJ, YANG R, FU XB and LIU YF. Overexpression of long non-coding RNA MALAT1 is correlated with clinical progression and unfavorable prognosis in pancreatic cancer. Tumor Biology 2015; 36: 2403-2407.

[21] ZHU HQ, ZHOU X, CHANG HL, H. G., LIU FF, MA CQ et al. Aberrant Expression of CCAT1 Regulated by c-Myc Predicts the Prognosis of Hepatocellular Carcinoma. Asian Pac J Cancer Prev 2015; 16: 5181-5185.

[22] SUN H, WANG G, PENG Y, ZENG Y, ZHU QN et al. H19 lncRNA mediates 17ß-estradiol-induced cell proliferation in MCF-7 breast cancer cells. Oncol Rep 2015; 33: 3045-3052.

[23] LUO M, LI Z, WANG W, ZENG Y, LIU Z et al. Long non-coding RNA H19 increases bladder cancer metastasis by associating with EZH2 and inhibiting E-cadherin expression. Cancer Lett 2013; 333: 213-221.

[24] LI H, YU B, LI J and YAN M. Overexpression of lncRNA H19 enhances carcinogenesis and metastasis of gastric cancer. Oncotarget 2014; 5: 2318-2329.

[25] XIE M, SUN M, ZHU YN, XIA R, LIU YW et al. Long noncoding RNA HOXA-AS2 promotes gastric cancer proliferation by epigenetically silencing P21/PLK3/DDIT3 expression. Oncotarget 2015; 6: 33587-33601.

[26] ZHAO H, ZHANG X, FRAZ O JB, CONDINO-NETO A and NEWBURGER PE. HOX antisense lincRNA HOXA-AS2 is an apoptosis repressor in all trans retinoic acid treated NB4 promyelocytic leukemia cells. J Cell Biochem 2013; 114: 2375-2383.

[27] XING Z, PARK PK, LIN C and YANG L. LncRNA BCAR4 wires up signaling transduction in breast cancer. RNA Biol 2015; 12: 681-689.

[28] ELLIS BC, MOLLOY PL and GRAHAM LD. CRNDE: A Long Non-Coding RNA Involved in Cancer, Neurobiology, and Development. Front Genet 2012; 3: 270.

[29] WANG Y, WANG Y, LI J, ZHANG Y, YIN H et al. CRNDE, a long-noncoding RNA, promotes glioma cell growth and invasion through mTOR signaling. Cancer Lett 2015; 367: 122-128.

[30] BO H, GONG Z, ZHANG W, LI X, ZENG Y et al. Upregulated long non-coding RNA AFAP1-AS1 expression is associated with progression and poor prognosis of nasopharyngeal carcinoma. Oncotarget 2015; 6: 20404-20418.

[31] DENG J, LIANG Y, LIU C, HE S and WANG S. The up-regulation of long non-coding RNA AFAP1-AS1 is associated with the poor prognosis of NSCLC patients. Biomed Pharmacother 2015; 75: 8-11.

[32] MA MZ, LI CX, ZHANG Y, WENG MZ, ZHANG MD et al. Long non-coding RNA HOTAIR, a c-Myc activated driver of malignancy, negatively regulates miRNA-130a in gallbladder cancer. Mol Cancer 2014; 13: 156.

[33] HEUBACH J, MONSIOR J, DEENEN R, NIEGISCH G, SZARVAS T et al. The long noncoding RNA HOTAIR has tissue and cell type-dependent effects on HOX gene expression and phenotype of urothelial cancer cells. Mol Cancer 2015; 14: 108.

[34] ZHANG L, ZHOU XF, PAN GF and ZHAO JP. Enhanced expression of long non-coding 
RNA ZXF1 promoted the invasion and metastasis in lung adenocarcinoma. Biomed Pharmacother 2014; 68: 401-407.

[35] HE W, CAI Q, SUN F, ZHONG G, WANG P et al. linc-UBC1 physically associates with polycomb repressive complex 2 (PRC2) and acts as a negative prognostic factor for lymph node metastasis and survival in bladder cancer. Biochem Biophys Acta 2013; 1832: 1528-1537.

[36] HU Y, PAN J, WANG Y, LI L and HUANG Y. Long noncoding RNA linc-UBC1 is negative prognostic factor and exhibits tumor pro-oncogenic activity in gastric cancer. Int J Clin Exp Pathol 2015; 8: 594-600.

[37] CUI Z, REN S, LU J, WANG F, XU W et al. The prostate cancer-up-regulated long noncoding RNA PlncRNA-1 modulates apoptosis and proliferation through reciprocal regulation of androgen receptor. Urol Oncol 2013; 31: 1117-1123.

[38] WANG CM, WU QQ, LI SQ, CHEN FJ, TUO L et al. Upregulation of the long non-coding RNA PIncRNA-1 promotes esophageal squamous carcinoma cell proliferation and correlates with advanced clinical stage. Dig Dis Sci 2014; 59: 591-597. 